Prepared in cooperation with Cobb County, Georgia

Flood-Inundation Maps for Sweetwater Creek from Above the Confluence of Powder Springs

Creek to the Interstate 20 Bridge, Cobb and Douglas Counties, Georgia

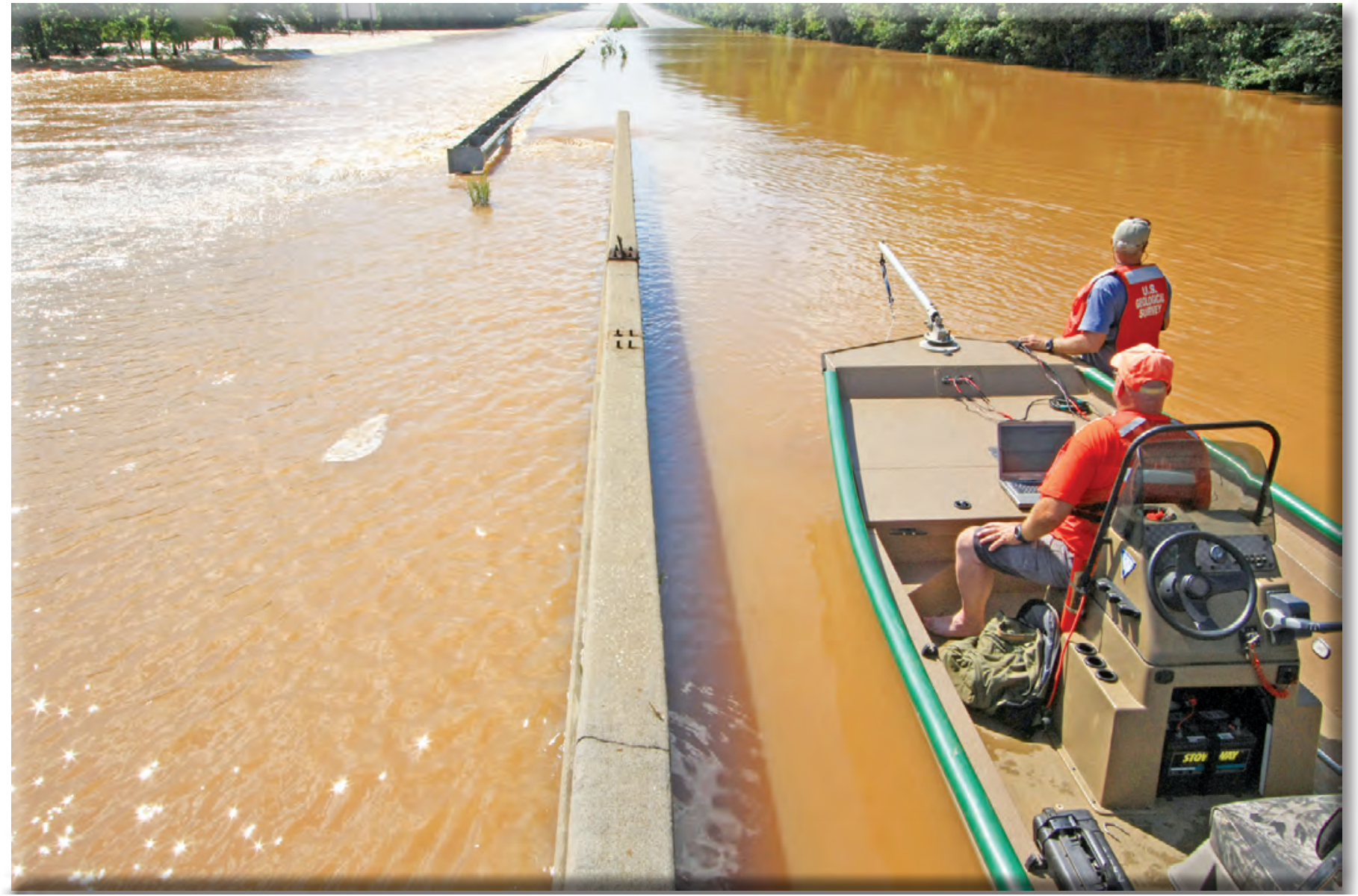

Pamphlet to accompany

Scientific Investigations Map 3220 
Cover. Measuring the flow of Sweetwater Creek over Interstate 20, September 22, 2009 (photograph by Alan M. Cressler, U.S. Geological Survey). 


\section{Flood-Inundation Maps for Sweetwater Creek from Above the Confluence of Powder Springs Creek to the Interstate 20 Bridge, Cobb and Douglas Counties, Georgia}

By Jonathan W. Musser

Prepared in cooperation with Cobb County, Georgia

Pamphlet to accompany

Scientific Investigations Map 3220 


\section{U.S. Department of the Interior \\ KEN SALAZAR, Secretary \\ U.S. Geological Survey \\ Marcia K. McNutt, Director}

\section{U.S. Geological Survey, Reston, Virginia: 2012}

For more information on the USGS - the Federal source for science about the Earth, its natural and living resources, natural hazards, and the environment, visit http://Www.usgs.gov or call 1-888-ASK-USGS

For an overview of USGS information products, including maps, imagery, and publications, visit $h$ ttp://www.usgs.gov/pubprod

To order this and other USGS information products, visit http://store.usgs.gov

Any use of trade, product, or firm names is for descriptive purposes only and does not imply endorsement by the U.S. Government.

Although this report is in the public domain, permission must be secured from the individual copyright owners to reproduce any copyrighted materials contained within this report.

Suggested citation:

Musser, J.W., 2012, Flood-inundation maps for Sweetwater Creek from above the confluence of Powder Springs Creek to the Interstate 20 bridge, Cobb and Douglas Counties, Georgia: U.S. Geological Survey Scientific Investigations Map 3220, 10 p. pamphlet, 21 sheets; available online at http://pubs.usgs.gov/sim/3220/. 


\section{Contents}

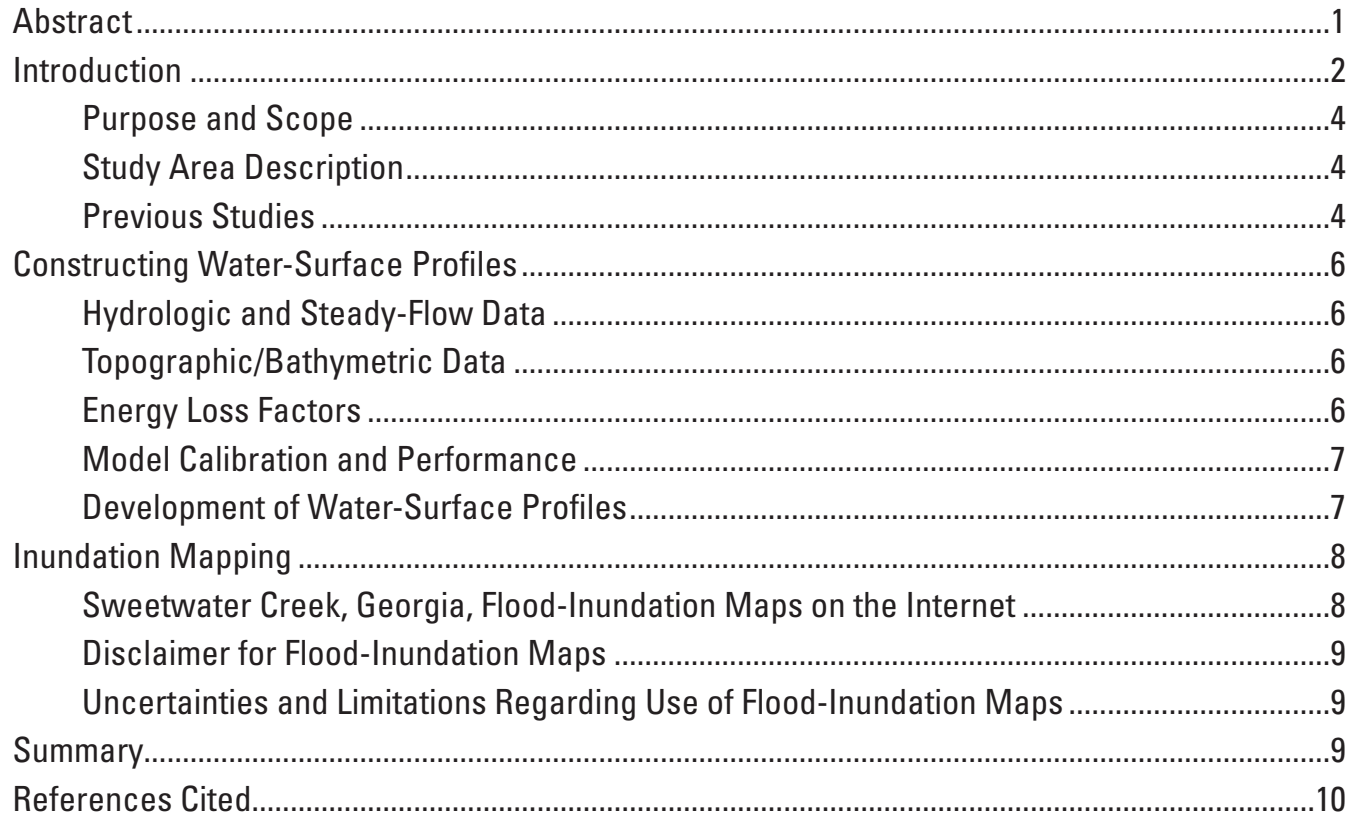

\section{Figures}

1. Map showing location of study reach for Sweetwater Creek and location of U.S. Geological Survey streamgages and National Weather Service (NWS) forecast site

2. Map showing Sweetwater Creek bridge crossings, model extent, and direction of surface-water flow .

\section{Tables}

1. Site information for U.S. Geological Survey streamgages in the Sweetwater Creek basin near Austell, Georgia .

2. Comparison of hydraulic-model output and surveyed high-water mark elevations from the flood of February 4, 1982, Sweetwater Creek, Georgia..

3. Stages (and water-surface elevations) with corresponding discharge estimates for selected simulated water-surface profiles at selected locations for the Sweetwater Creek near Austell, Georgia, streamgage (02337000)

4. Stream stages and water-surface elevations at Sweetwater Creek near Austell, Georgia, streamgage (02337000), with reference to corresponding map-sheet numbers in this report. 


\section{Sheets (Each sheet has individual pdf and jpg files available for download. For links, see http://pubs.usgs.gov/sim/3220/.)}

1-21. Maps showing flood-Inundation of Sweetwater Creek in Cobb and Douglas Counties, Georgia, corresponding to a gage height and an elevation (NAVD 88) as listed below at U.S. Geological Survey streamgage Sweetwater Creek near Austell, Georgia (02337000)—

1. Gage height of 12.0 feet and an elevation of 869.3 feet

2. Gage height of 13.0 feet and an elevation of 870.3 feet

3. Gage height of 14.0 feet and an elevation of 871.3 feet

4. Gage height of 15.0 feet and an elevation of 872.3 feet

5. Gage height of 16.0 feet and an elevation of 873.3 feet

6. Gage height of 17.0 feet and an elevation of 874.3 feet

7. Gage height of 18.0 feet and an elevation of 875.3 feet

8. Gage height of 19.0 feet and an elevation of 876.3 feet

9. Gage height of 20.0 feet and an elevation of 877.3 feet

10. Gage height of 21.0 feet and an elevation of 878.3 feet

11. Gage height of 22.0 feet and an elevation of 879.3 feet

12. Gage height of 23.0 feet and an elevation of 880.3 feet

13. Gage height of 24.0 feet and an elevation of 881.3 feet

14. Gage height of 25.0 feet and an elevation of 882.3 feet

15. Gage height of 26.0 feet and an elevation of 883.3 feet

16. Gage height of 27.0 feet and an elevation of 884.3 feet

17. Gage height of 28.0 feet and an elevation of 885.3 feet

18. Gage height of 29.0 feet and an elevation of 886.3 feet

19. Gage height of 30.0 feet and an elevation of 887.3 feet

20. Gage height of 31.0 feet and an elevation of 888.3 feet

21. Gage height of 32.0 feet and an elevation of 889.3 feet 


\section{Conversion Factors and Datums}

\begin{tabular}{lcl}
\hline \multicolumn{1}{c}{ Multiply } & By & \multicolumn{1}{c}{ To obtain } \\
\hline inch & Length & millimeter $(\mathrm{mm})$ \\
foot $(\mathrm{ft})$ & 25.4 & meter $(\mathrm{m})$ \\
mile $(\mathrm{mi})$ & 0.3048 & kilometer $(\mathrm{km})$ \\
\hline & 1.609 & \\
\hline square foot $\left(\mathrm{ft}^{2}\right)$ & Area & square meter $\left(\mathrm{m}^{2}\right)$ \\
square mile $\left(\mathrm{mi}^{2}\right)$ & 0.0929 & square kilometer $\left(\mathrm{km}^{2}\right)$ \\
\hline & 2.590 & \\
\hline cubic foot per second $\left(\mathrm{ft}^{3} / \mathrm{s}\right)$ & Flow rate & cubic meter per second $\left(\mathrm{m}^{3} / \mathrm{s}\right)$ \\
\hline & 0.02832 & meter per kilometer $\left(\mathrm{m} / \mathrm{km}^{2}\right)$ \\
\hline foot per mile $(\mathrm{ft} / \mathrm{mi})$ & Hydraulic gradient & \\
\hline
\end{tabular}

Vertical coordinate information is referenced to the North American Vertical Datum of 1988 (NAVD 88).

Horizontal coordinate information is referenced to the North American Datum of 1983 (NAD 83).

Elevation, as used in this report, refers to the distance above NAVD 88.

Stage, as used in this report, is the elevation of the water surface above an arbitrary datum established at the gage (gage datum).

\section{Acronyms and Additional Abbreviations}

$\begin{array}{ll}\text { AHPS } & \text { Advanced Hydrologic Prediction Service } \\ \text { DFIRM } & \text { Digital Flood Insurance Rate Map } \\ \text { FEMA } & \text { Federal Emergency Management Agency } \\ \text { GIS } & \text { geographic information system } \\ \text { NED } & \text { National Elevation Dataset } \\ \text { NWS } & \text { National Weather Service } \\ \text { USGS } & \text { U.S. Geological Survey }\end{array}$

\section{Acknowledgments}

The author wishes to thank Cobb County for funding operation and maintenance of streamgages used for this study. Special thanks are given to the National Weather Service for their continued support to the U.S. Geological Survey flood-inundation mapping initiative. 



\title{
Flood-Inundation Maps for Sweetwater Creek from Above the Confluence of Powder Springs Creek to the Interstate 20 Bridge, Cobb and Douglas Counties, Georgia
}

\author{
By Jonathan W. Musser
}

\section{Abstract}

Digital flood-inundation maps for a 10.5-mile reach of Sweetwater Creek, from about 1,800 feet above the confluence of Powder Springs Creek to about 160 feet below the Interstate 20 bridge, were developed by the U.S. Geological Survey (USGS) in cooperation with Cobb County, Georgia. The inundation maps, which can be accessed through the USGS Flood Inundation Mapping Science Web site at http://water.usgs.gov/osw/flood_inundation/, depict estimates of the areal extent and depth of flooding corresponding to selected water levels (stages) at the USGS streamgage at Sweetwater Creek near Austell, Georgia (02337000). Current stage at this USGS streamgage may be obtained at http://waterdata.usgs.gov/ and can be used in conjunction with these maps to estimate near real-time areas of inundation. The National Weather Service (NWS) is incorporating results from this study into the Advanced Hydrologic Prediction Service

(AHPS) flood-warning system (http:/water.weather.gov/ahps/). The NWS forecasts flood hydrographs at many places that commonly are collocated at USGS streamgages. The forecasted peak-stage information for the USGS streamgage at Sweetwater Creek near Austell (02337000), which is available through the AHPS Web site, may be used in conjunction with the maps developed in this study to show predicted areas of flood inundation.
A one-dimensional step-backwater model was developed using the U.S. Army Corps of Engineers HEC-RAS software for Sweetwater Creek and was used to compute flood profiles for a 10.5-mile reach of the creek. The model was calibrated using the most current stage-discharge relations at the Sweetwater Creek near Austell streamgage (02337000), as well as high-water marks collected during annual peak-flow events in 1982 and 2009. The hydraulic model was then used to determine 21 water-surface profiles for flood stages at the Sweetwater Creek streamgage at 1-foot intervals referenced to the streamgage datum and ranging from just above bankfull stage (12.0 feet) to approximately 1.2 feet above the highest recorded water level at the streamgage (32.0 feet). The simulated water-surface profiles were then combined with a geographic information system digital elevation modelderived from contour data (8-foot horizontal resolution), in Cobb County, and USGS National Elevation Dataset (31-foot horizontal resolution), in Douglas County - to delineate the area flooded for each 1-foot increment of stream stage.

The availability of these maps, when combined with real-time information regarding current stage from USGS streamgages and forecasted stream stages from the NWS, provides emergency management personnel and residents with critical information during flood-response activities, such as evacuations and road closures, as well as for post-flood recovery efforts. 


\section{Introduction}

Cobb and Douglas Counties, Georgia (Ga.), are suburban communities with populations of 688,078 and 132,403 , respectively, in 2010 (U.S. Census Bureau, 2011; fig. 1). Land use within the flood plain of Sweetwater Creek is widely varied with a mix of residential, recreational, and commercial structures, and areas of agriculture, grass fields, wetlands, and forest. In recent years, Cobb and Douglas Counties have experienced severe flooding that has caused substantial damage along Sweetwater Creek. The floods of July 2005 and September 2009 are two such notable events. Austell, Ga., which is in the southern part of Cobb County, was particularly affected by the 2009 event.

Prior to this study, Cobb and Douglas County officials and officials from the City of Austell have relied on several information sources (available on the Internet) to make decisions on how best to alert the public and mitigate flood damages along Sweetwater Creek. One source of information is the Federal Emergency Management Agency (FEMA) Digital Flood Insurance Rate Map (DFIRM) (Federal Emergency Management Agency, 2011). A second source of information is the U.S. Geological Survey (USGS) streamgage - Sweetwater Creek near Austell, Ga. (02337000) - from which current or historical water levels (stage) can be obtained (table 1). Stage is the height of the water surface above an arbitrary datum established at the gage (gage datum). A third source is the National Weather Service (NWS) forecast of peak stage at the USGS Sweetwater Creek near Austell streamgage (forecast site AUSG1) through the Advanced Hydrologic Prediction Service (AHPS) Web site at http:/water.weather.gov/ahps/. The USGS has six additional gages located within the Sweetwater Creek basin where current and historical stages can be obtained.

Although USGS current stage and NWS forecast stage information is particularly useful for residents in the immediate vicinity of a streamgage, it is of limited use to residents farther upstream or downstream because the water-surface elevation is not constant along the entire stream channel. Also, FEMA and State emergency management mitigation teams or property owners typically lack information related to water depth at locations other than locations near USGS streamgages or NWS flood-forecast points. To help guide the general public in taking individual safety precautions and provide local officials with a tool to help efficiently manage emergency flood operations and flood-mitigation efforts, digital flood-inundation maps for a 10.5-mile reach of Sweetwater Creek, from about 1,800 feet above the confluence of Powder Springs Creek to about 160 feet below the Interstate 20 bridge, were developed by the USGS in cooperation with Cobb County, Georgia.

Table 1. Site information for U.S. Geological Survey streamgages in the Sweetwater Creek basin near Austell, Georgia.

[USGS, U.S. Geological Survey; Ga., Georgia; current year, year of publication; ft, feet; mi, mile; see fig. 1 for station locations]

\begin{tabular}{|c|c|c|c|c|c|c|}
\hline \multirow{2}{*}{ Station name } & \multirow{2}{*}{$\begin{array}{l}\text { USGS } \\
\text { station } \\
\text { number }\end{array}$} & \multirow{2}{*}{$\begin{array}{c}\text { Drainage } \\
\text { area, in } \\
\text { square miles }\end{array}$} & Latitude & Longitude & \multirow{2}{*}{ Period of record } & \multirow{2}{*}{$\begin{array}{l}\text { Maximum } \\
\text { recorded stage } \\
\text { at gage and date }\end{array}$} \\
\hline & & & \multicolumn{2}{|c|}{ (degrees, minutes, seconds) } & & \\
\hline $\begin{array}{l}\text { Sweetwater Creek near } \\
\quad \text { Austell, Ga. }\end{array}$ & 02337000 & 246 & $33^{\circ} 46^{\prime} 35^{\prime \prime}$ & $84^{\circ} 36^{\prime} 56^{\prime \prime}$ & 1937 to current year & $\begin{array}{c}30.82 \mathrm{ft} \\
\text { Sept. } 22,2009\end{array}$ \\
\hline $\begin{array}{l}\text { Sweetwater Creek at } \\
\text { Brownsville Road, near } \\
\text { Powder Springs, Ga. }\end{array}$ & 02336840 & 102 & $33^{\circ} 49^{\prime} 38^{\prime \prime}$ & $84^{\circ} 43^{\prime} 11^{\prime \prime}$ & 2007 to current year & $\begin{array}{c}31.40 \mathrm{ft} \\
\text { Sept. } 21,2009\end{array}$ \\
\hline $\begin{array}{l}\text { Sweetwater Creek } 0.05 \mathrm{mi} \\
\text { upstream of Norfolk } \\
\text { Southern Railroad bridge } \\
\text { at Austell, Ga. }\end{array}$ & 02336910 & 157 & $33^{\circ} 49^{\prime} 04^{\prime \prime}$ & $84^{\circ} 39^{\prime} 00^{\prime \prime}$ & 2010 to current year & $\begin{array}{c}14.52 \mathrm{ft} \\
\text { Apr. } 16,2011\end{array}$ \\
\hline $\begin{array}{l}\text { Sweetwater Creek below } \\
\text { Austell, Ga. }\end{array}$ & 02337040 & 262 & $33^{\circ} 43^{\prime} 15^{\prime \prime}$ & $84^{\circ} 36^{\prime} 54^{\prime \prime}$ & 1998 to current year & $\begin{array}{c}38.0 \mathrm{ft} \\
\text { Sept. } 22,2009\end{array}$ \\
\hline $\begin{array}{l}\text { Powder Springs Creek near } \\
\text { Powder Springs, Ga. }\end{array}$ & 02336870 & 17.3 & $33^{\circ} 51^{\prime} 33^{\prime \prime}$ & $84^{\circ} 41^{\prime} 17^{\prime \prime}$ & 2007 to current year & $\begin{array}{c}19.91 \mathrm{ft} \\
\text { Sept. } 21,2009\end{array}$ \\
\hline $\begin{array}{l}\text { Noses Creek at Powder } \\
\text { Springs Road, Powder } \\
\text { Springs, Ga. }\end{array}$ & 02336968 & 44.5 & $33^{\circ} 51^{\prime} 33^{\prime \prime}$ & $84^{\circ} 39^{\prime} 10^{\prime \prime}$ & 1998 to current year & $\begin{array}{c}23.21 \mathrm{ft} \\
\text { Sept. } 22,2009\end{array}$ \\
\hline $\begin{array}{l}\text { Olley Creek at Clay Road, } \\
\text { near Austell, Ga. }\end{array}$ & 02336986 & 13.5 & $33^{\circ} 50^{\prime} 10^{\prime \prime}$ & $84^{\circ} 37^{\prime} 54^{\prime \prime}$ & 2007 to current year & $\begin{array}{c}27.39 \mathrm{ft} \\
\text { Sept. } 22,2009\end{array}$ \\
\hline
\end{tabular}



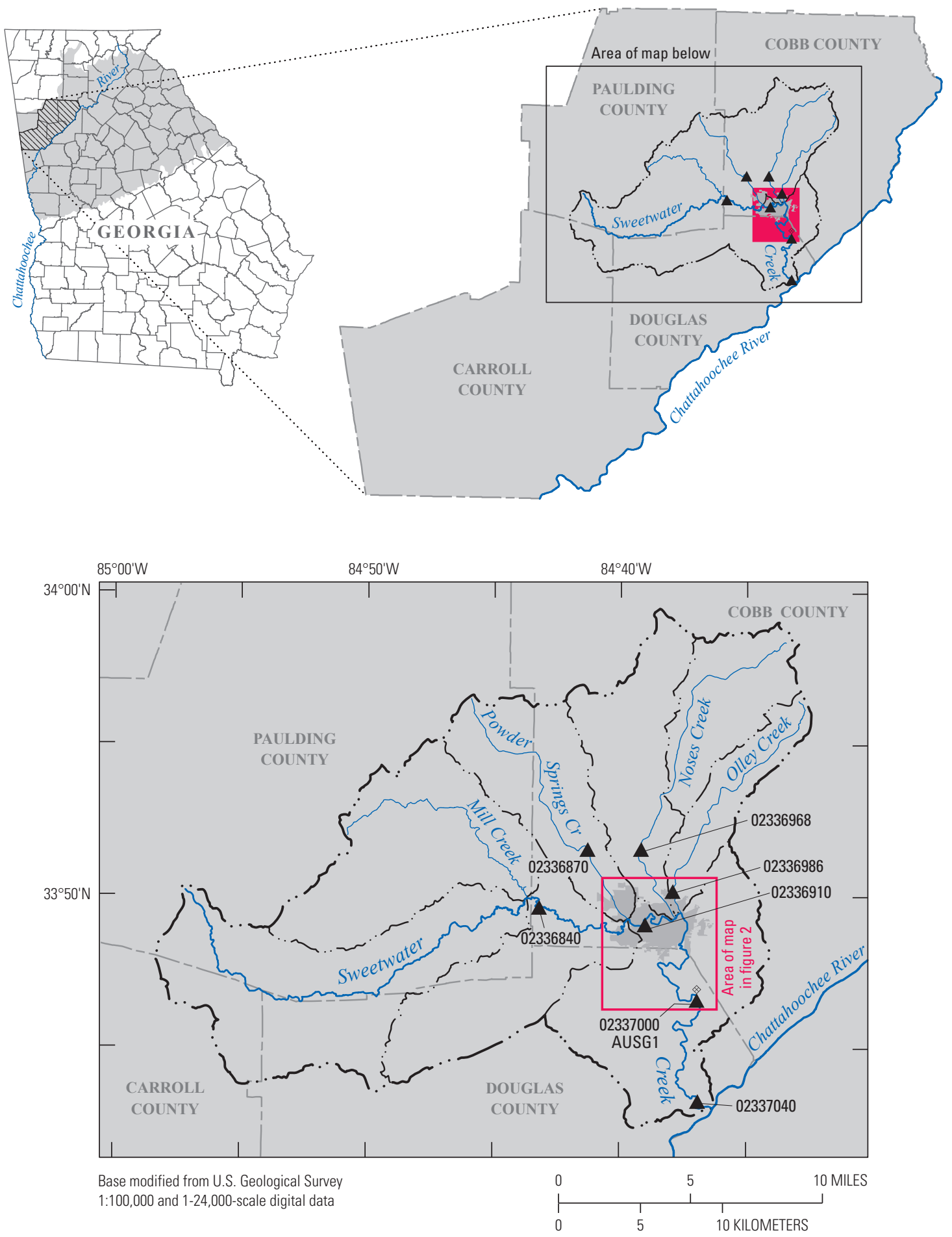

EXPLANATION

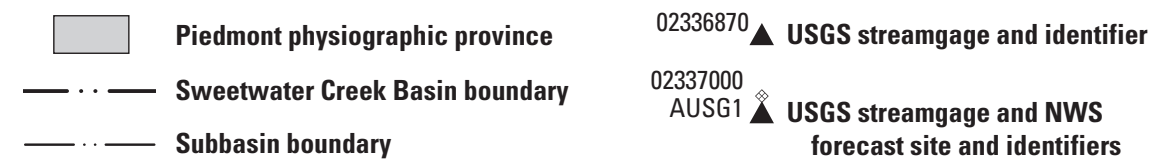

Figure 1. Location of study reach for Sweetwater Creek and location of U.S. Geological Survey streamgages and National Weather Service (NWS) forecast site. 
Flood-Inundation Maps for Sweetwater Creek, Cobb and Douglas Counties, Georgia

\section{Purpose and Scope}

The purpose of this report is to describe the development of a series of estimated flood-inundation maps for Sweetwater Creek in Cobb and Douglas Counties, Ga. The maps and other flood information are available on the USGS Flood Inundation Mapping Science Web site at http://water.usgs.gov/osw/ flood_inundation/ and the previously mentioned NWS AHPS Web site. Internet users can select estimated inundation maps that correspond to (1) current stages at the USGS streamgage near Austell (02337000), (2) the NWS forecasted peak stage, or (3) other desired stream stages.

The scope of the study was limited to a 10.5-mile reach of Sweetwater Creek from about 1,800 feet (ft) above the confluence of Sweetwater Creek and Powder Springs Creek to about $160 \mathrm{ft}$ downstream of the Interstate 20 bridge (fig. 2). Tasks specific to development of the flood-inundation maps were (1) analysis of the flow and stage data collected at two streamgages, Sweetwater Creek near Austell (02337000) and Sweetwater Creek at Brownsville Road near Powder Springs (02336840) (table 1), as well as flow and stage data recorded at numerous locations along the reach during the 1982 and 2009 peak-flow events; (2) collection of topographic data and geometric data (for structures, bridges, and the stream channel) throughout the study reach; (3) determination of energy-loss factors (roughness coefficients) in the stream channel and flood plain; (4) computation of water-surface profiles using the U.S. Army Corps of Engineers HEC-RAS computer program (U.S. Army Corps of Engineers, Hydrologic Engineering Center, 2010); (5) production of estimated flood-inundation maps at various stream stages using the U.S. Army Corps of Engineers HEC-GeoRAS computer program (U.S. Army Corps of Engineers, Hydrologic Engineering Center, 2009) and a geographic information system (GIS); and (6) development of a Web-site interface that links to USGS real-time streamgage information and (or) NWS forecasted peak stage to facilitate the display of user-selected flood-inundation maps on the Internet.

Methods used generally are cited from previously published reports (Bales and others, 2007; Whitehead and Ostheimer, 2009). If techniques varied substantially from previously documented methods because of local hydrologic conditions or available data, they are described in detail in this report. Maps were produced for water levels referenced to the stage at Sweetwater Creek near Austell (02337000) and ranged from approximately bankfull $(12.0 \mathrm{ft})$ to above the maximum observed water level at the streamgage $(32.0 \mathrm{ft})$.

\section{Study Area Description}

Sweetwater Creek is in northern Georgia in the Piedmont physiographic province (Clark and Zisa, 1976). The drainage area ranges from 128 square miles $\left(\mathrm{mi}^{2}\right)$ at the junction of
Powder Springs Creek to $246 \mathrm{mi}^{2}$ at the Sweetwater Creek near Austell streamgage (02337000), the downstream extent of the study reach (fig. 2). The headwaters of Sweetwater Creek originate in Paulding County (fig. 1). Sweetwater Creek and its tributaries generally flow eastward through Paulding, Carroll, Cobb, and Douglas Counties until the junction with Olley Creek. From there, the flow direction is generally southward until Sweetwater Creek joins with the Chattahoochee River.

Four major tributaries flow into Sweetwater Creek. From upstream to downstream, they are Powder Springs Creek, Noses Creek, Olley Creek, and Butternut Creek. The USGS monitors flow on Powder Springs Creek, Noses Creek, and Olley Creek with the following gages: Powder Springs Creek near Powder Springs (02336870), Noses Creek at Powder Springs Road, Powder Springs (02336968), and Olley Creek at Clay Road, near Austell (02336986). In addition, Sweetwater Creek below Austell (02337040) is located on Sweetwater Creek near where it flows into the Chattahoochee River (fig. 1).

The basin terrain is gently rolling with stream valleys that are fairly deep and narrow and lie 100 to $200 \mathrm{ft}$ below the narrow, rounded stream divides (Clark and Zisa, 1976). The study reach is about 10.5 miles (mi) long, with an average channel slope of about 1.9 feet per mile ( $\mathrm{ft} / \mathrm{mi})$. The land that is contiguous to the study reach is mostly classified as developed, with some areas classified as forest. Some large areas of woody wetlands are along Sweetwater Creek and its tributaries (Fry and others, 2011). The main channel within the study reach has nine major road bridges and two rail bridges that cross the channel and the adjacent flood plain.

\section{Previous Studies}

The current DFIRM for Cobb County was published June 18, 2010, and the DFIRM for Douglas County was published August 18, 2009 (Federal Emergency Management Agency, 2011). The DFIRMs were used to check the inundation extent for discharges that are close to the 1-percent and 0.2-percent annual exceedance probability. Two HEC-RAS models of Sweetwater Creek were obtained in 2011 from Sam Crampton at Dewberry, an engineering firm contracted by FEMA. These models were used in the development of the DFIRMs. The two HEC-RAS models were combined for use in this study, and the cross sections, stream channel lengths, and bridge details within the study area were used as a starting point for creation of the model used in this study.

Similar studies that provide flood-inundation maps for a range of stream stages were completed in Albany, Ga., for the Flint River (Musser and Dyar, 2007) and in Atlanta, Ga., for Peachtree Creek (Musser, 2012). The methods for the Flint River model used a finite-element two-dimensional model, which differed from those of the Sweetwater Creek model. The methods used for the Peachtree Creek model were similar to those used for the Sweetwater Creek model. 


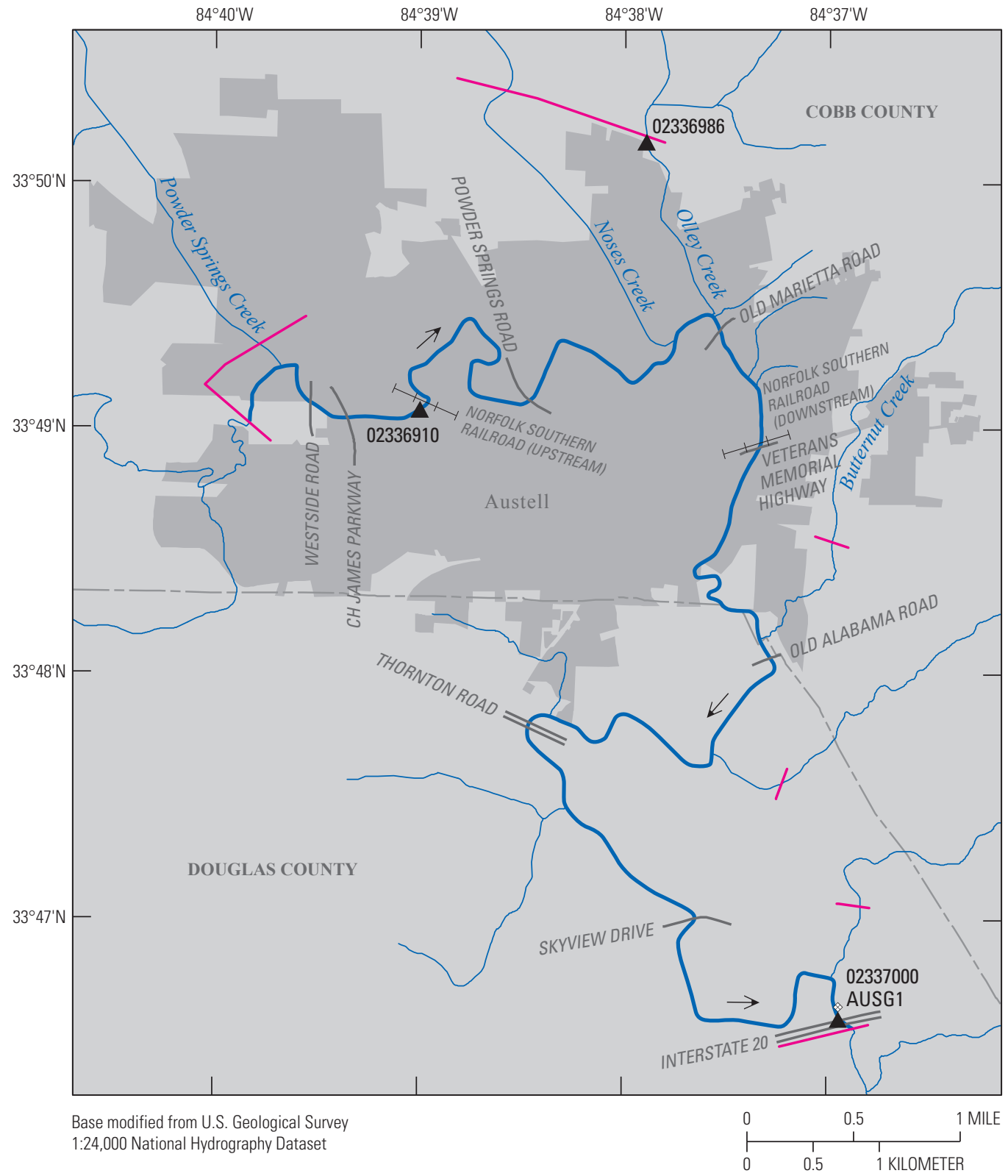

\section{EXPLANATION}

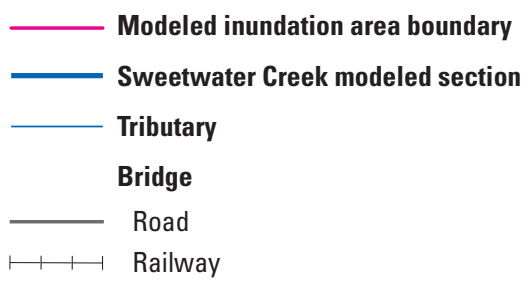

02336910 USGS streamgage and identifier

02337000

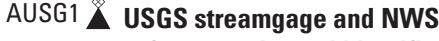

forecast site and identifiers

$\rightarrow \quad$ Direction of surface-water flow

$\longmapsto \perp$ Railway

Figure 2. Sweetwater Creek bridge crossings, model extent, and direction of surface-water flow. 


\section{Constructing Water-Surface Profiles}

The water-surface profiles used to produce the 21 flood-inundation maps in this study were computed using HEC-RAS, version 4.1.0 (U.S. Army Corps of Engineers, Hydrologic Engineering Center, 2010). HEC-RAS is a one-dimensional step-backwater model for simulation of water-surface profiles with steady-state (gradually varied) or unsteady-state flow computation options. For this study, the HEC-RAS analysis was completed by using the steady-state flow computation option.

\section{Hydrologic and Steady-Flow Data}

The hydrologic network in the study area consists of two streamgages on the study reach and one streamgage upstream of the study reach (fig. 1; table 1). The Sweetwater Creek near Austell (02337000) and Sweetwater Creek at Brownsville Road, near Powder Springs (02336840) streamgages were used in this study to determine flow values for HEC-RAS along the study reach. The streamgage identified as Sweetwater Creek 0.05 mi upstream of Norfolk Southern Railroad bridge at Austell (02336910) was installed in 2010, and the defined stage-discharge relation (as of 2012) does not extend beyond bankfull stage into the flood zone. Water level (stage) is measured continuously, and continuous records of streamflow are computed at all of the sites. All water-surface elevations are referenced to North American Vertical Datum of 1988 (NAVD 88). The gages are equipped with satellite radio transmitters that allow data to be transmitted routinely and made available on the Internet within an hour of collection. The gaging stations on Sweetwater Creek 0.05 mi upstream of Norfolk Southern Railroad bridge at Austell (02336910) and Sweetwater Creek at Brownsville Road, near Powder Springs also are equipped with a recording rain gage. Longitudinal water-surface profiles from high-water marks along the main channel were documented following floods in 1982 and 2009. The 1982 high-water marks were used for model calibration. The 2009 high-water marks were affected by large amounts of debris at the bridges, so they were of limited use in calibration. High-water marks were not available for the 2005 flood.

Steady-flow data consisted of flow regime, boundary conditions (stage and discharge values), and peak discharge information. Steady-flow data for the study reach were obtained by using the stage-discharge relation at the Sweetwater Creek near Austell streamgage (02337000) and the Sweetwater Creek at Brownsville Road, near Powder Springs (02336480) streamgage as well as the historic peak stage and flow information available for both of these streamgages. Steady-flow data were also obtained from historical peak stage and flow information available at various bridge crossings along Sweetwater Creek for the 1982 annual peak event.

\section{Topographic/Bathymetric Data}

The cross sections from the HEC-RAS models, obtained from Dewberry, were used as a starting point for the model used in this study. Hereafter, the term "original" will be used to describe the model as obtained from Dewberry. Additional cross sections were added to the model where the distance between original cross sections was more than $500 \mathrm{ft}$. The elevations of the in-channel portion of the new cross sections were calculated by interpolating between original cross sections. The overbank elevations of the new cross sections were calculated from a raster elevation dataset. The source for the raster elevation in Cobb County was an 8 - $\mathrm{ft}$ by 8 -ft cell raster from photogrammatically derived contours. The source for the raster elevation in Douglas County is the USGS 1/3-Arc Second National Elevation Dataset (NED), with a cell size of approximately $31 \mathrm{ft}$ by $31 \mathrm{ft}$. The NED was resampled to $8 \mathrm{ft}$ by $8 \mathrm{ft}$ to match the resolution of the Cobb County data. Additional elevation data in the area of the Old Alabama Road bridge were obtained by survey. The survey data were collected using a Topcon GTS-210 Total Station and a survey rod.

Various drainage structures (bridges, culverts, roadway embankments, levees, and dams) in and along the stream affect or have the potential to affect water-surface elevations during floods along the stream. To properly account for these features in the model, structural dimensions for 11 bridges were measured and surveyed in the field as part of the original HEC-RAS model. The bridges in the original HEC-RAS model were visually verified during site visits. The bridges from upstream to downstream were Westside Road, C.H. James Parkway, Norfolk Southern Railroad (upstream), Powder Springs Road, Old Marietta Road, Norfolk Southern Railroad (downstream), Veterans Memorial Highway, Old Alabama Road, Thornton Road, Skyview Drive, and Interstate 20 (fig. 2). A detailed description of the methods used to acquire and process the topographic and bathymetric data can be found in Bales and others (2007).

\section{Energy Loss Factors}

Field observations and high-resolution aerial photographs were used to select initial (precalibration) Manning's roughness coefficients (" $n$ " values) for energy (friction) loss calculations. The final Manning's $n$ values ranged from 0.075 to 0.095 for the main channel. The Manning's $n$ values ranged from 0.033 (grass) to 0.26 (forested areas with heavy undergrowth) for the overbank areas modeled in this analysis. The Manning's $n$ values from the original model were not used because they did not match the land-cover characteristics in many locations. Additionally, more flows were simulated than in the original HEC-RAS model. 


\section{Model Calibration and Performance}

The hydraulic model was calibrated to the most current (2011) stage-discharge relation at the Sweetwater Creek near Austell streamgage (02337000) and to high-water marks collected during the 1982 and 2009 annual peak-flow events. The estimated peak discharge for the 1982 flood was 10,700 cubic feet per second $\left(\mathrm{ft}^{3} / \mathrm{s}\right)$ at an estimated stage of about $19.90 \mathrm{ft}$ at the gage. For the $2009 \mathrm{flood}$, the estimated peak discharge was $31,500 \mathrm{ft}^{3} / \mathrm{s}$ at an estimated stage of about $30.82 \mathrm{ft}$. Model calibration was accomplished by adjusting Manning's $n$ values until the results of the hydraulic computations closely agreed with the known flood discharge and stage values for the 1982 flood profile. During the 2009 flood, a large amount of debris accumulated on many bridges resulting in higher water surfaces than would be expected for the flow. The simulated water surface was between 0.4 and $2.0 \mathrm{ft}$ lower than the measured high-water marks from the 2009 flood. Differences between measured and simulated water levels for models calibrated to the 1982 flood were between -0.1 and $+0.1 \mathrm{ft}$ (table 2). The boundaries of the DFIRM flood zones were similar to the boundaries of the modeled inundated areas from the 21-ft stage Sweetwater Creek flood-inundation model. These results demonstrate that the model is capable of simulating accurate water levels over a wide range of flows in the basin. Details on techniques used in model development and calibration can be found in Bales and others (2007).

\section{Development of Water-Surface Profiles}

Profiles were developed for 21 stages at 1.0-ft intervals between 12.0 and $32.0 \mathrm{ft}$, as referenced to the Sweetwater
Creek near Austell streamgage (02337000). Discharges at the streamgage corresponding to the various stages were obtained from the most current stage-discharge relation (rating no. 22.1). Discharges for all profiles were calculated based on a ratio of streamflow to drainage area for historical events. Table 3 lists results for stages at 2-ft increments from 12 to $32 \mathrm{ft}$. A relation of yield (flow per drainage area) and drainage area was calculated based on the historical discharges from Sweetwater Creek at Brownsville Road, near Powder Springs (02336840) downstream to Sweetwater Creek near Austell (02337000). This relation was then used to determine discharge estimates along the model reach for the 21 stages. Stages and discharge estimates for selected locations and profiles are shown in table 3.

Table 2. Comparison of hydraulic-model output and surveyed high-water mark elevations from the flood of February 4, 1982, Sweetwater Creek, Georgia.

[Values listed in feet above North American Vertical Datum of 1988]

\begin{tabular}{lccc}
\hline $\begin{array}{c}\text { Location along } \\
\text { Sweetwater Creek }\end{array}$ & $\begin{array}{c}\text { High-water } \\
\text { mark } \\
\text { elevation }\end{array}$ & $\begin{array}{c}\text { Modeled } \\
\text { water-surface } \\
\text { elevations }\end{array}$ & $\begin{array}{c}\text { Elevation } \\
\text { difference }\end{array}$ \\
\hline Skyview Drive & 880.6 & 880.6 & 0.0 \\
Old Alabama Road & 888.7 & 888.7 & 0.0 \\
$\begin{array}{l}\text { Veterans Memorial } \\
\quad \text { Highway }\end{array}$ & 891.2 & 891.1 & -0.1 \\
$\begin{array}{l}\text { Norfolk Southern } \\
\quad \text { Railway } \\
\quad \text { upstream) }\end{array}$ & 893.6 & 893.5 & -0.1 \\
$\quad$ & & \\
Westside Road & 897.7 & 897.8 & +0.1 \\
\hline
\end{tabular}

Table 3. Stages (and water-surface elevations) with corresponding discharge estimates for selected simulated water-surface profiles at selected locations for the Sweetwater Creek near Austell, Georgia, streamgage (02337000).

[Values 12.0-32.0 represent stage, in feet above gage datum. Values in parentheses (869.3-889.3) are water-surface elevations, in feet above North American Vertical Datum 1988; Ga., Georgia]

\begin{tabular}{|c|c|c|c|c|c|c|c|c|c|c|c|}
\hline Location & \multicolumn{11}{|c|}{ Water-surface elevations and discharge estimates } \\
\hline \multicolumn{12}{|c|}{ Stage, in feet } \\
\hline $\begin{array}{l}\text { Sweetwater Creek } \\
\text { near Austell, Ga. }\end{array}$ & $\begin{array}{c}12.0 \\
(869.3)\end{array}$ & $\begin{array}{c}14.0 \\
(871.3)\end{array}$ & $\begin{array}{c}16.0 \\
(873.3)\end{array}$ & $\begin{array}{c}18.0 \\
(875.3)\end{array}$ & $\begin{array}{c}20.0 \\
(877.3)\end{array}$ & $\begin{array}{c}22.0 \\
(879.3)\end{array}$ & $\begin{array}{c}24.0 \\
(881.3)\end{array}$ & $\begin{array}{c}26.0 \\
(883.3)\end{array}$ & $\begin{array}{c}28.0 \\
(885.3)\end{array}$ & $\begin{array}{c}30.0 \\
(887.3)\end{array}$ & $\begin{array}{c}32.0 \\
(889.3)\end{array}$ \\
\hline \multicolumn{12}{|c|}{ Discharge, in cubic feet per second } \\
\hline $\begin{array}{l}\text { Below Powder } \\
\text { Springs Creek }\end{array}$ & 3,560 & 4,390 & 5,330 & 6,890 & 9,190 & 11,800 & 15,000 & 18,800 & 23,200 & 28,200 & 33,500 \\
\hline Below Olley Creek & 4,230 & 5,220 & 6,320 & 8,060 & 10,400 & 13,200 & 16,400 & 20,200 & 24,400 & 29,100 & 33,900 \\
\hline At Old Alabama Road & 4,300 & 5,300 & 6,420 & 8,180 & 10,600 & 13,300 & 16,600 & 20,300 & 24,500 & 29,200 & 34,000 \\
\hline $\begin{array}{c}\text { Sweetwater Creek } \\
\text { near Austell } \\
\text { streamgage }\end{array}$ & 4,430 & 5,460 & 6,600 & 8,400 & 10,700 & 13,600 & 16,800 & 20,500 & 24,700 & 29,300 & 34,000 \\
\hline
\end{tabular}




\section{Inundation Mapping}

Flood-inundation maps were created based on the Sweetwater Creek near Austell streamgage (02337000), which has been designated as an NWS flood-forecast point (AUSG1). The maps were created in a GIS by combining the water-surface profiles and digital elevation model data. The digital elevation model data were derived in two parts. The Cobb County elevation data are from an 8 - $\mathrm{ft}$ by 8 - $\mathrm{ft}$ cell raster from photogrammatically derived contours. The Douglas County elevation data are from the USGS 1/3-Arc Second NED, with a cell size of approximately $31 \mathrm{ft}$ by $31 \mathrm{ft}$. Estimated flood-inundation boundaries for each simulated profile were developed with HEC-GeoRAS software (U.S. Army Corps of Engineers, Hydrologic Engineering Center, 2009). HEC-GeoRAS is a set of procedures, tools, and utilities for processing geospatial data in ArcGIS (Esri, 2010) by using a graphical user interface (Whitehead and Ostheimer, 2009). The interface allows the preparation of geometric data for import into HEC-RAS and processes simulation results exported from HEC-RAS (U.S. Army Corps of Engineers, Hydrologic Engineering Center, 2010). HEC-GeoRAS results were modified to ensure a hydraulically reasonable transition of the boundary between modeled cross sections relative to the contour data for the land surface (Whitehead and Ostheimer, 2009). The resulting inundation maps have a vertical accuracy of about $0.5 \mathrm{ft}$ in Cobb County and $2.0 \mathrm{ft}$ in Douglas County. The maps show estimated flood-inundated areas overlain on high-resolution, georeferenced, aerial photographs of the study area for each of the water-surface profiles that were generated by the hydraulic model. The bed slope of Sweetwater Creek is fairly consistent from Powder Springs Creek to Old Alabama Road. The bed slope is then steeper downstream to Thornton Road where the bed slope becomes flatter to the Sweetwater
Creek near Austell streamgage (02337000) at Interstate 20. The reach of Sweetwater Creek included in the inundation maps is about $10.5 \mathrm{mi}$ long. The sheet numbers corresponding to each 1-ft stage increment at the Sweetwater Creek streamgage are shown in table 4.

The flood-inundation maps could be extended further upstream once additional data are collected to extend the stage-discharge relation into the flood zone at the Sweetwater Creek 0.05 mi upstream of Norfolk Southern Railroad bridge at Austell, Ga., streamgage (02336910). Additionally flood-inundation maps could be created based on the other streamgages within the Sweetwater Creek basin.

\section{Sweetwater Creek, Georgia, Flood-Inundation Maps on the Internet}

A USGS Flood Inundation Mapping Science World Wide Web portal (http://water.usgs.gov/osw/flood_inundation/) has been established by the USGS to provide estimated floodinundation information to the public. The maps from this study are available in several commonly used electronic file formats that can be downloaded from that portal. Each stream reach displayed on the Web site contains links to the USGS National Water Information System graphs of the current stage and streamflow at the USGS Sweetwater Creek near Austell streamgage (02337000), to which the inundation maps are referenced. A link also is provided to the NWS AHPS Web site (http:/water.weather.gov/ahps/) so that the user can obtain applicable information on forecasted peak stage. The estimated flood-inundation maps are displayed in sufficient detail to note the extent of flooding with respect to individual structures so that preparations for flooding and decisions for emergency response can be performed efficiently.

Table 4. Stream stages and water-surface elevations at Sweetwater Creek near Austell, Georgia, streamgage (02337000), with reference to corresponding map-sheet numbers in this report.

[Values 12.0-32.0 represent stage, in feet above gage datum. Values in parentheses (869.3-889.3) represent water-surface elevation in feet above North American Vertical Datum 1988]

\begin{tabular}{|c|c|c|c|c|c|c|c|c|c|c|c|}
\hline \multicolumn{12}{|c|}{ Sweetwater Creek near Austell } \\
\hline Sheet number & 1 & 2 & 3 & 4 & 5 & 6 & 7 & 8 & 9 & 10 & 11 \\
\hline $\begin{array}{l}\text { Stage (water- } \\
\text { surface } \\
\text { elevation) }\end{array}$ & $\begin{array}{c}23.0 \\
(880.3)\end{array}$ & $\begin{array}{c}24.0 \\
(881.3)\end{array}$ & $\begin{array}{c}25.0 \\
(882.3)\end{array}$ & $\begin{array}{c}26.0 \\
(883.3)\end{array}$ & $\begin{array}{c}27.0 \\
(884.3)\end{array}$ & $\begin{array}{c}28.0 \\
(885.3)\end{array}$ & $\begin{array}{c}29.0 \\
(886.3)\end{array}$ & $\begin{array}{c}30.0 \\
(887.3)\end{array}$ & $\begin{array}{c}31.0 \\
(888.3)\end{array}$ & $\begin{array}{c}32.0 \\
(889.3)\end{array}$ & \\
\hline Sheet number & 12 & 13 & 14 & 15 & 16 & 17 & 18 & 19 & 20 & 21 & \\
\hline
\end{tabular}




\section{Disclaimer for Flood-Inundation Maps}

Inundated areas shown should not be used for navigation, regulatory, permitting, or other legal purposes. The USGS provides these maps "as-is" for a quick reference, emergency planning tool but assumes no legal liability or responsibility resulting from the use of this information.

\section{Uncertainties and Limitations Regarding Use of Flood-Inundation Maps}

Although the flood-inundation maps represent the boundaries of inundated areas with a distinct line, some uncertainty is associated with these maps. The flood boundaries shown were estimated based on water stages and streamflows at selected USGS streamgages. Water-surface elevations along the stream reaches were estimated by steady-state hydraulic modeling, assuming unobstructed flow, and by using streamflows and hydrologic conditions anticipated at the USGS streamgage(s). The hydraulic model reflects the land-cover characteristics and any bridge, dam, levee, or other hydraulic structures existing as of September 2011. Unique meteorological factors (timing and distribution of precipitation) may cause actual streamflows along the modeled reach to vary from those assumed during a flood, which may lead to deviations in the water-surface elevations and inundation boundaries shown. Additional areas may be flooded due to unanticipated conditions such as changes in the streambed elevation or roughness, backwater into major tributaries along a main stem river, or backwater from localized debris or ice jams. The accuracy of the floodwater extent portrayed on these maps will vary with the accuracy of the digital elevation model used to simulate the land surface. Additional uncertainties and limitations pertinent to this study are described elsewhere in this report.

If this series of flood-inundation maps will be used in conjunction with National Weather Service (NWS) river forecasts, the user should be aware of additional uncertainties that may be inherent or factored into NWS forecast procedures. The NWS uses forecast models to estimate the quantity and timing of water flowing through selected stream reaches in the United States. These forecast models (1) estimate the amount of runoff generated by precipitation and snowmelt, (2) simulate the movement of floodwater as it proceeds downstream, and (3) predict the flow and stage (and watersurface elevation) for the stream at a given location (AHPS forecast point) throughout the forecast period (every 6 hours and 3 to 5 days out in many locations). For more information on AHPS forecasts, please see http://water.weather.gov/ahps/ pcpn_and_river_forecasting.pdf.

\section{Summary}

A series of estimated flood-inundation maps were developed by the U.S. Geological Survey (USGS), in cooperation with Cobb County, Georgia, for a 10.5-mile reach of Sweetwater Creek from about 1,800 feet above the confluence with Powder Springs Creek to about 160 feet below the Interstate 20 bridge. These maps, available at a USGS Web portal, in conjunction with the real-time stage data from the USGS streamgage at Sweetwater Creek near Austell, Georgia (02337000), and National Weather Service flood-stage forecasts, can help to guide the general public in taking individual safety precautions and can provide local officials with a tool to help efficiently manage emergency flood operations and flood-mitigation efforts.

The maps were developed using the U.S. Army Corps of Engineers HEC-RAS and HEC-GeoRAS computer programs to simulate water-surface profiles and to delineate estimated flood-inundation areas for selected stream stages. The maps show estimated flood-inundation areas overlain on high-resolution, georeferenced, aerial photographs of the study area for 1.0-foot increments of stream stage between 12.0 and 32.0 feet (gage datum) at the Sweetwater Creek near Austell, Georgia, streamgage (02337000). 


\section{References Cited}

Bales, J.D., Wagner, C.R., Tighe, K.C., and Terziotti, Silvia, 2007, LiDAR-derived flood-inundation maps for realtime flood-mapping applications, Tar River Basin, North Carolina: U.S. Geological Survey Scientific Investigations Report 2007-5032, 42 p.

Clark, W.Z., Jr., and Zisa, A.C., 1976, Physiographic map of Georgia: Georgia Geologic Survey, scale 1:2,000,000.

Esri, ArcGIS Desktop: Version 9.3.1: accessed August 2010 at http://www.esri.com/.

Federal Emergency Management Agency, Digital Flood Insurance Rate Map: accessed March 2011 at http://www.msc.fema.gov/.

Fry, J.A., Xian, G., Jin, S., Dewitz, J.A., Homer, C.G., Yang, L., Barnes, C.A., Herold, N.D., and Wickham, J.D., 2011, Completion of the 2006 National Land Cover Database for the conterminous United States: Photogrammetric Engineering \& Remote Sensing, v. 77, no. 9, p. 858-864.

Musser, J.W., 2012, Flood-inundation maps for Peachtree Creek from the Norfolk Southern Railway bridge to the Moores Mill Road NW bridge, Atlanta, Georgia: U.S. Geological Survey Scientific Investigations Map 3189, 9 p., 50 sheets, available online at http://pubs.usgs.gov/sim/3189/.
Musser, J.W., and Dyar, T.R., 2007, Two-dimensional floodinundation model of the Flint River at Albany, Georgia: U.S. Geological Survey Scientific Investigations Report 2007-5107, 49 p., available online at http://pubs.usgs.gov/sir/2007/5107/.

U.S. Army Corps of Engineers, Hydrologic Engineering Center, 2009, HEC-GeoRAS, GIS Tools for Support of HEC-RAS using ArcGIS: User's Manual, version 4.2 [variously paged].

U.S. Army Corps of Engineers, Hydrologic Engineering Center, 2010, HEC-RAS River Analysis System: Hydraulic Reference Manual, version 4.1 [variously paged].

U.S. Census Bureau, State and County QuickFacts: accessed November 2011, at http://quickfacts.census.gov/qfd/index.html.

Whitehead, M.T., and Ostheimer, C.J., 2009, Development of a flood-warning system and flood-inundation mapping for the Blanchard River in Findlay, Ohio: U.S. Geological Survey Scientific Investigations Report 2008-5234, 9 p. 
Manuscript approved on June 26, 2012

Edited by Kimberly A. Waltenbaugh Illustrations and layout by Caryl J. Wipperfurth

Science Publishing Network, Raleigh PSC

For more information about this publication, contact: USGS Georgia Water Science Center

3039 Amwiler Road

Atlanta, GA 30360

telephone: $770-903-9100$

http://ga.water.usgs.gov/ 
